Photogallery

\title{
Bleaching in the Ryukyu Islands in 2016 and associated Degree Heating Week threshold
}

\author{
Hajime KAYANNE ${ }^{1 *}$, Rintaro SUZUKI ${ }^{2}$, and Gang LIU $^{3}$ \\ ${ }^{1}$ Department of Earth and Planetary Science, University of Tokyo, Hongo, Tokyo 113-0033, Japan \\ ${ }^{2}$ Coral Reef Conservation and Research Center, WWF Japan, Shiraho, Ishigaki, Okinawa 907-0242, Japan \\ ${ }^{3}$ Coral Reef Watch, U.S. National Oceanic and Atmospheric Administration, College Park, Maryland 20740, USA; \\ Global Science and Technology, Inc., Greenbelt, Maryland 20770, USA \\ * Corresponding author: H. Kayanne \\ E-mail: kayanne@eps.s.u-tokyo.ac.jp
}

Communicated by Michio Hidaka (Biology Editor)

Keywords bleaching, 2016, Ryukyu Islands, northwest Pacific, degree heating week, global warming

In the summer of 2016, coral reefs in the Ryukyu Islands, Japan suffered from extensive bleaching. The most severe bleaching occurred in Ishigaki Island, with 90\% and 40-55\% corals bleached in Sekisei Lagoon and Shiraho Reef, respectively (Fig. 1a). In Okinawa, $50-80 \%$ of corals were bleached (Fig. 1b). This event was part of a global bleaching event starting in the Mariana Islands in June 2014 and expanding to the South Pacific and Indian Ocean in 2015 and the northern Great Barrier Reef in March 2016 (Hughes et al., 2017) followed by the Ryukyu Islands. The progress of the event was similar to that of 1997-1998 associated with a strong El Niño and finished in the Ryukyu Islands.

The spatial distribution of the 2016 bleaching was highly heterogeneous in the northwestern Pacific: most severe in Ishigaki and severe in Okinawa in the southern Ryukyus; moderate in Amami in the northern Ryukyus; limited in Kochi and Kushimoto along the mainland Japan; and only mild or no bleaching in Ogasawara, Guam, and Palau (Electronic Supplementary Material Table $\left.1^{*}\right)$. The severity of the observed bleaching matched well spatially with NOAA Coral Reef Watch's near real-time satellite $50 \mathrm{~km}$ coral bleaching Degree Heating Week (DHW) (Liu et al., 2013 ) for these sites: the highest values in Ishigaki $\left(10.7^{\circ} \mathrm{C}\right.$-weeks) and Okinawa (10.5), high in Amami (8.2), moderate in Kochi
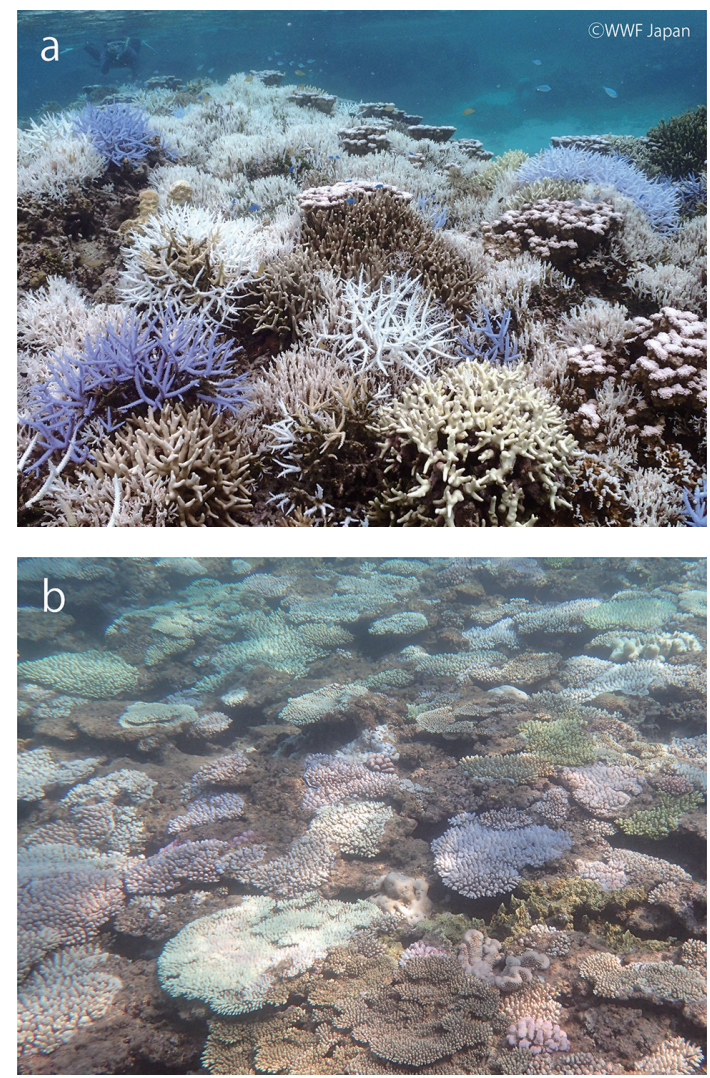

Fig. 1 Photos showing severe bleaching in the southern Ryukyu Islands in 2016. a Shiraho Reef at the southeast coast of Ishigaki Island on 10 August. b Sesoko Island in Okinawa on 31 August. 
(6.2), Kushimoto (7.8) and Ogasawara (4.8), and low in Guam (1.4) and Palau (2.3).

This event further confirmed that the DHW value of $8^{\circ} \mathrm{C}$-weeks can be used as a threshold for widespread bleaching (Liu et al., 2013), and validates Kayanne (2017) in which historical observation of bleaching and DHW from 1982 to

2015 was compared. A DHW of $8^{\circ} \mathrm{C}$-weeks corresponds to a one-month averaged anomaly of $2^{\circ} \mathrm{C}$ during the warmest season of the year, a thermal environment that could be easily attained under projected $2^{\circ} \mathrm{C}$ global warming.

\section{References}

Hughes TP et al. (2017) Global warming and recurrent mass bleaching of corals. Nature 543: 373-377

Kayanne H (2017) Validation of degree heating weeks as a coral bleaching index in the northwestern Pacific. Coral Reefs 36: $63-70$

Liu G, Rauenzahn JL, Heron SF, Eakin CM, Skirving WJ, Christensen TRL, Strong AE (2013) NOAA coral reef watch $50 \mathrm{~km}$ satellite sea surface temperature-based decision support system for coral bleaching management. NOAA Technical Report NESDIS 143, NOAA, Washington DC, 33pp

* ESM Table 1 can be downloaded from the J-STAGE website: https://www.jstage.jst.go.jp/browse/galaxea/19/0/_contents

Received: 28 February 2017/Accepted: 15 April 2017

(C) Japanese Coral Reef Society 